\title{
IMPLEMENTASI METODE USABILITY TESTING DENGAN SYSTEM USABILITY SCALE DALAM PENILAIAN WEBSITE RS SILOAM PALEMBANG
}

\author{
Nurul Huda \\ Universitas Bina Darma, Fakultas Ilmu Komputer \\ Jl. A. Yani No. 12, Palembang 30624, Indonesia \\ email: nurul_huda@binadarma.ac.id
}

\begin{abstract}
This research was conducted to find out how effective and efficient the Siloam Hospital Palembang website is located at www.siloamhospitals.com and can be accessed by all people to get faster information and updates and measure the satisfaction and convenience of website users for users. Website needs to be evaluated seen from the ease of learning, ease of use, using a questionnaire. The method used in satisfaction measurement can use the usability testing method and system usability scale. Measurements using the usability testing method are conducted to assess whether the interaction between users and applications can run well and the System Usability Scale has 10 statements as testing tools and does not require a large number of samples. The results of the assessment of the usability scale system will provide input for future website development to be even better.
\end{abstract}

Keywords: website, usability testing, system usability scale

\begin{abstract}
Abstrak
Penelitian ini dilakukan untuk mengetahui seberapa efektif dan efisiennya website RS Siloam Palembang yang beralamat www.siloamhospitals.com dan dapat diakses oleh seluruh orang untuk mendapatkan informasi yang lebih cepat dan update serta mengukur kepuasan dan kemudahan pengguna website bagi pengguna. Website perlu dilakukan evaluasi dilihat dari kemudahan untuk dipelajari, kemudahan untuk digunakan, dengan menggunakan kuesioner. Metode yang digunakan dalam pengukuran kepuasan dapat menggunakan metode usability testing dan system usability scale. Pengukuran dengan metode usability testing dilakukan untuk menilai apakah interaksi antara pengguna dengan aplikasi dapat berjalan dengan baik dan System Usability Scale mempunyai 10 pernyataan sebagai alat pengujian dan tidak memerlukan jumlah sampel yang banyak. Hasil dari penilaian system usability scale ini akan memberikan masukan untuk pengembangan website ke depan agar lebih baik lagi.
\end{abstract}

Kata kunci: website, usability testing, system usability scale

\section{PENDAHULUAN}


RS Siloam Palembang merupakan salah satu Rumah Sakit di Kota Palembang yang telah memiliki Website sendiri dengan beberapa fitur informasi dan juga bantuan untuk pengunjung (masyarakat) RS Siloam Palembang tersebut. Website merupakan salah satu sumber informasi yang sangat penting guna menunjang proses pelayanan lembaga kesehatan khususnya Rumah Sakit (RS). Website merupakan penyedia informasi yang sangat penting, apalagi kebutuhan pegawai dan masyarakat akan adanya informasi sangat tinggi [1]. Website yang dimiliki RS Siloam Palembang ini merupakan salah satu bentuk pelayanan yang diberikan untuk kemudahan pengunjung (masyarakat) dalam memperoleh informasi terkait dengan RS Siloam Palembang. Selama ini website RS Siloam Palembang belum pernah dilakukan penilaian terhadap tingkat efektif dan efisiennya dalam penggunaan website tersebut. Oleh karena itu, pada penelitian ini dilakukan penilaian terhadap website RS Siloam Palembang dengan menerapkan metode Usability Testing dengan System Usability Scale. Hasil dari penelitian ini dapat dijadikan acuan dalam meningkatkan kualitas website yang telah digunakan pada RS Siloam Palembang karena pelayanan terhadap masyarakat dan karyawan yang haus akan informasi haruslah ditingkatkan. Dengan semakin tingginya minat Pegawai dan Masyarakat untuk menggali informasi melalui jaringan internet atau website, tentunya pihak Teknologi informasi memikirkan bagaimana cara meningkatkan kualitas pelayanan penggunaan website RS Siloam Palembang baik dengan melakukan perbaikan, perubahan ataupun pengembangan website sesuai dengan kebutuhan pengguna website tersebut.

Struktur website RS Siloam Palembang, terdiri dari halaman-halaman yang menunjukan fungsinya masing-masing diantaranya, menu home, Our hospital, Our specialities, Plan your visit, Media Coverage dan Career with us dari berbagai jenis menu halaman tersebut tersimpan berbagai macam informasi yang dapat kita peroleh dengan mengakses website tersebut, akan tetapi untuk menyampaikan informasi melalui website tidaklah semudah yang kita lihat akan tetapi diperlukan desain yang baik serta mudah dipahami oleh pengguna agar website tersebut dapat diterima oleh masyarakat, maka dari itu sangat diperlukan evaluasi terhadap website, dengan adanya evaluasi terhadap website maka kelemahan yang ada di website tersebut dapat diperbaiki guna terbentuknya website yang menyajikan informasi yang tepat efisien serta mudah di mengerti [2].

Metode yang digunakan dalam penilaian website adalah metode yang merupakan metode untuk mengukur efisiensi, kemudahan dipelajari, dan kemampuan untuk mengingat bagaimana berinteraksi tanpa kesulitan atau kesalahan. Metode ini digunakan untuk meningkatkan kemudahan pengguna selama proses desain. Metode Usability Testing perlu mencakup lima hal yaitu [3]:

a. Learnability, secara sederhana dapat dikatakan bahwa sistem harus mudah dipelajari sehingga pemakai dapat secepatnya mulai menyelesaikan pekerjaan dengan menggunakan sistem. 
b. Efficiency, sistem hendaknya efisen penggunannya sehingga pemakai yang telah mempelajari sistem dapat mencapai tingkat produktivitas yang tinggi.

c. Memorability, suatu sistem seharusnya mudah diingat sehingga setelah meninggalkan sistem untuk beberapa waktu pemakai yang telah biasa menggunakannya tetap dapat menggunakannya tanpa harus mempelajari dari awal.

d. Errors, sistem seharusnya memiliki kesalahan yang rendah sehingga pemakai akan sedikit melakukan kesalahan ketika menggunakan sistem dan apabila pemakai melakukan kesalahan makadapat memperbaikinya dengan mudah.

e. Satisfaction, sistem nyaman untuk digunakan sehingga memuaskan pemakainya.

[4] mengatakan bahwa: "In mostcases,I tend to think the ideal number of users for each round of testing is three, or atmost four". Atau bisa diartikan dalam "kebanyakan kasus, saya cenderung berpikir jumlah pengguna yang ideal untuk setiap lingkaran pengujian tiga, atau sampai empat paling banyak". pemilihan responden yang akan memberikan isian terhadap kuisioner sejumlah 3 (tiga) orang dengan pemisahan yaitu satu orang bagian IT (terampil menggunakan internet dan sering mengakses situs website tersebut), satu orang perawat (terampil menggunakan internet) dan satu orang pengguna awam.

Pengukuran usability dilakukan untuk menilai apakah interaksi antara pengguna dengan aplikasi dapat berjalan denganbaik. Pengukuran dilakukan mengikuti konsep user testing, dengan penekanan pada pengukuran dan bukan pengujian, sebagai berikut:

a. Menentukan tujuan dalam mengeksplorasi pertanyaan.

b. Memilih paradigma dan teknik pengukuran dalam usability.

c. Merancang task yang akan menjadi sarana pengukuran.

d. Memilih partisipan yang akan menjadi pengguna untuk mencoba aplikasi.

e. Mempersiapkan kondisi pengukuran.

f. Merencanakan jalannya pengukuran.

g. Melakukan evaluasi, analisis dan penyajian data.

Pengukuran dilakukan dalam rangka mengidentifikasi permasalahan usability yang dapat mempengaruhi interaksi sistem (perangkat lunak) dengan pengguna pada hasil perancangan aplikasi. Pengukuran dengan menguji cobakan perangkat lunak aplikasi kepada sejumlah partisipan (bertindak sebagai responden pengguna aplikasi) sambil melakukan obsrvasi. Selanjutnya partisipan dimana mengisi kuesioner untuk memperoleh gambaran tingkat kepuasan dalam pengoperasian aplikasi. Masukan dari partisipan digunakan sebagai umpan balik dalam melengkapi prasyarat fungsional maupun kebutuhan interaksi pengguna. Pada tabel 1 di bawah ini terlihat beberapa pertanyaan yang diajukan kepada Responden. 
Tabel 1: Pertanyaan untuk Responden

\begin{tabular}{|c|c|c|c|c|c|}
\hline PERTANYAAN & STS & TS & $\mathbf{N}$ & $\mathbf{S}$ & SS \\
\hline $\begin{array}{l}\text { 1. Saya pikir saya ingin sering menggunakan } \\
\text { sistem ini }\end{array}$ & & & & $\mathrm{X}$ & \\
\hline $\begin{array}{l}\text { 2. Saya menemukan bahwa sistem ini tidak } \\
\text { perlu serumit ini }\end{array}$ & & & $\mathrm{X}$ & & \\
\hline 3. Saya pikir sistem itu mudah digunakan & & & & $\mathrm{X}$ & \\
\hline $\begin{array}{l}\text { 4. Saya pikir saya perlu bantuan orang teknis } \\
\text { dalam menggunakan sistem ini }\end{array}$ & & $\mathrm{X}$ & & & \\
\hline $\begin{array}{l}\text { 5. Saya menemukan berbagai fungsi dalam } \\
\text { sistem ini terintegrasi dengan baik }\end{array}$ & & & & $\mathrm{X}$ & \\
\hline $\begin{array}{l}\text { 6. Saya fikir ada terlalu banyak ketidak } \\
\text { konsistenan dalam sistem ini }\end{array}$ & & & $\mathrm{X}$ & & \\
\hline $\begin{array}{l}\text { 7. Saya akan membayangkan bahwa } \\
\text { kebanyakan orang akan belajar }\end{array}$ & & & $\mathrm{X}$ & & \\
\hline $\begin{array}{l}\text { 8. Saya menemukan sistem ini sangat tidak } \\
\text { praktis untuk digunakan }\end{array}$ & & $\mathrm{X}$ & & & \\
\hline $\begin{array}{l}\text { 9. Saya merasa sangat percaya diri dengan } \\
\text { menggunakan sistem ini }\end{array}$ & & $\mathrm{X}$ & & & \\
\hline $\begin{array}{l}\text { 10. Saya perlu banyak belajar sebelum saya } \\
\text { menggunakan sistem ini }\end{array}$ & & & $\mathrm{X}$ & & \\
\hline
\end{tabular}

\section{Keterangan:}

STS : Sangat tidak setuju

TS : Tidak setuju

$\mathrm{N} \quad$ : Netral

S : Setuju

SS : Sangat setuju

\section{METODOLOGI PENELITIAN}

Dalam rangka penyelesaian penelitian ini maka digunakan metode penelitian Action Research yang merupakan salah satu bentuk rancangan penelitian. Di dalam metode penelitian action research, peneliti mendeskripsikan, menginterpretasi dan menjelaskan suatu situasi sosial pada waktu yang bersamaan dengan melakukan perubahan atau intervensi dengan tujuan perbaikan atau partisipasi [5]. Berikut pada gambar 1 adalah gambar dan penjelasan terhadap tahapan metode penelitian action research yang digunakan pada penelitian ini, yaitu [6]:

a. Melakukan diagnosa (diagnosing)

b. Membuat rencana tindakan (action planning)

c. Melakukan tindakan (action taking) 

d. Melakukan evaluasi (evaluating)
e. Pembelajaran (learning)

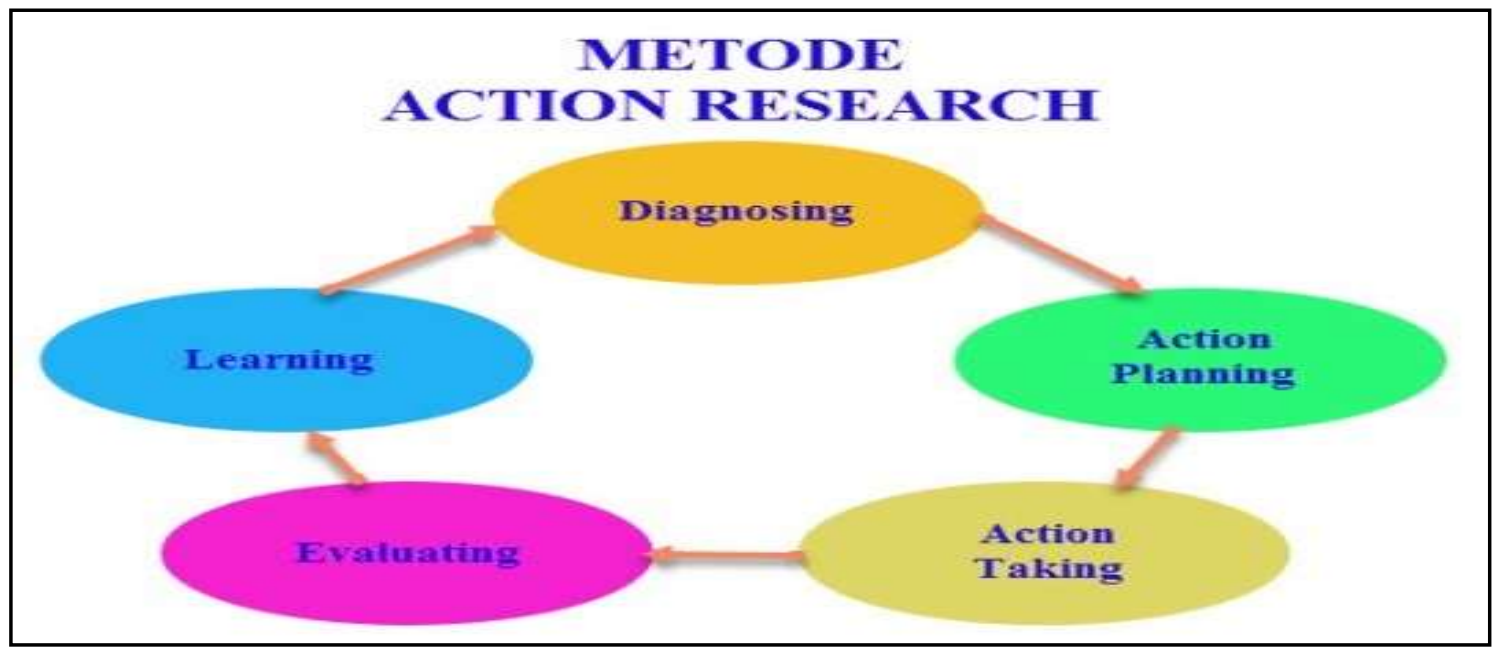

Gambar 1: Metode Action Research

\section{HASIL DAN PEMBAHASAN}

\subsection{Populasi dan Sampel}

Dalam penelitian kualitatif tidak menggunakan istilah populasi, tetapi oleh Spradley dinamakan socialsituation atau situasi sosial. Sampel yang diambil dari populasi adalah pengguna yang akan dijadikan responden [7]. Pengguna yang akan dijadikan sampel harus mewakili dari semua populasi (pengguna), maka akan diambil sampel yang mewakili tiga tingkatan pengguna dan dalam penelitian ini diambil sepuluh responden yang mewakili populasi, yaitu:

a. Pengguna Aktif yaitu pengguna terampil dalam komputer dan internet.

b. Pengguna Terampil yaitu pengguna yang terampil internet.

c. Pengguna Awam yaitu pengguna yang baru tau internet.

Berdasarkan dalam penelitian ini sampel yang digunakan sebanyak 10 orang responden yang berhubungan dengan rumah sakit siloam palembang. Pada gambar 2 hingga gambar 15 berikut ini dapat dilihat tampilan dari website yang saat ini digunakan pada RS Siloam Palembang. 


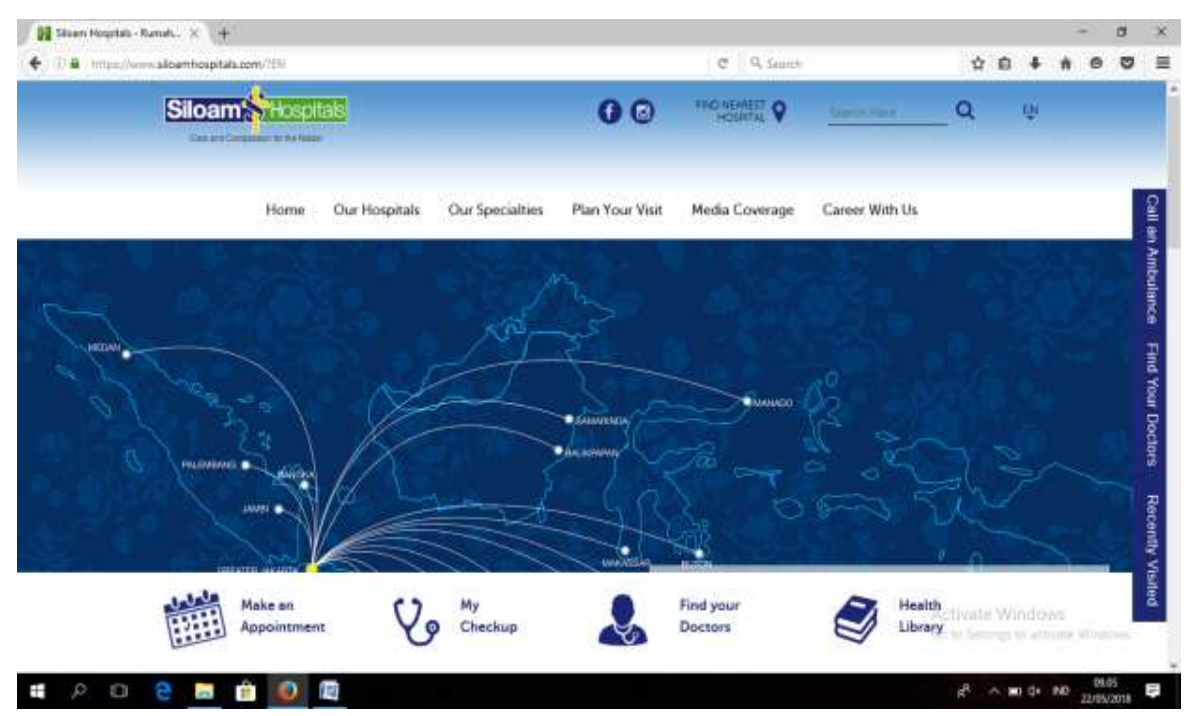

Gambar 2: Halaman depan website RS Siloam Palembang.

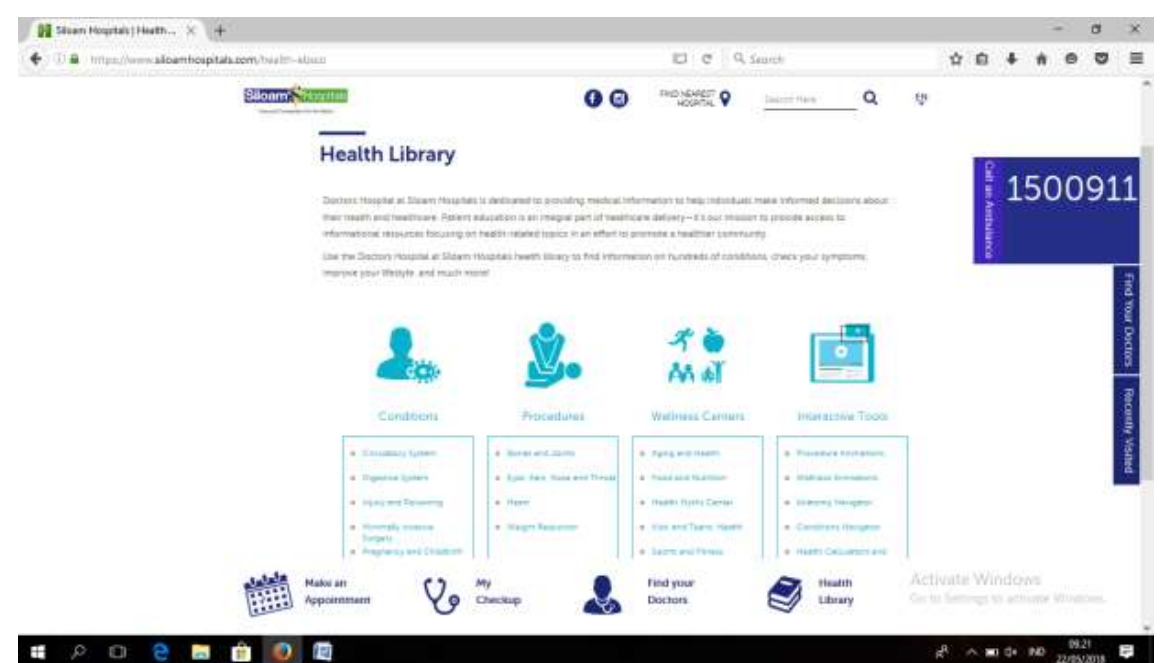

Gambar 3: Tampilan menu call an ambulance.

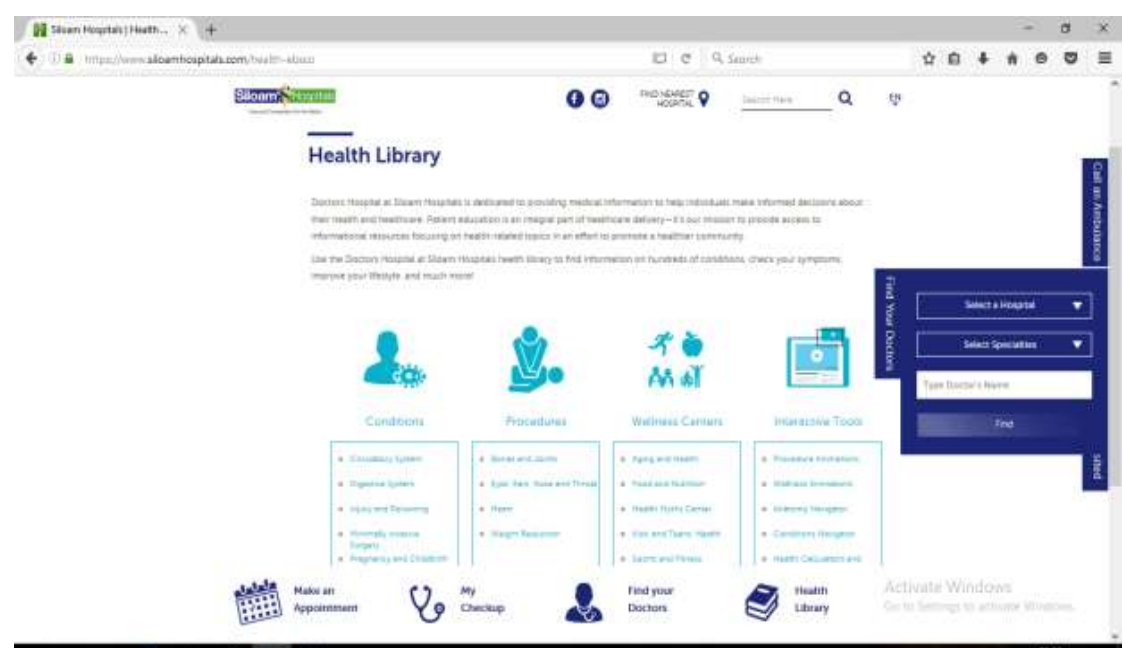

Gambar 4: Tampilan find your doctor. 


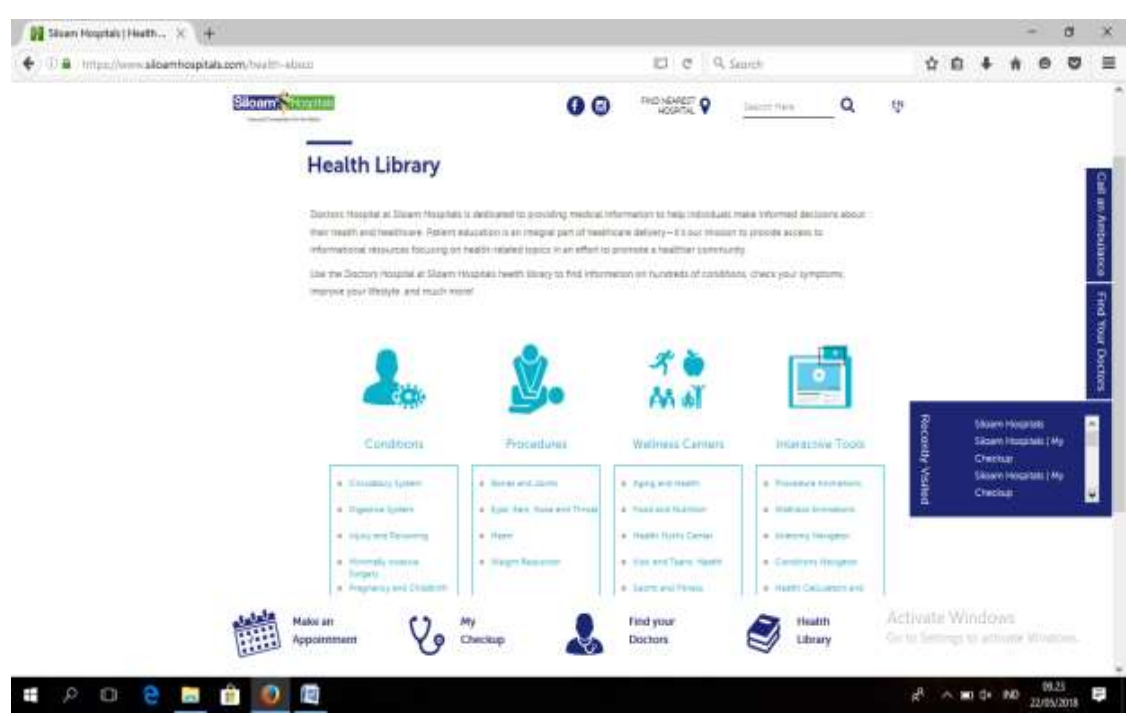

Gambar 5: Tampilan Recently visited.

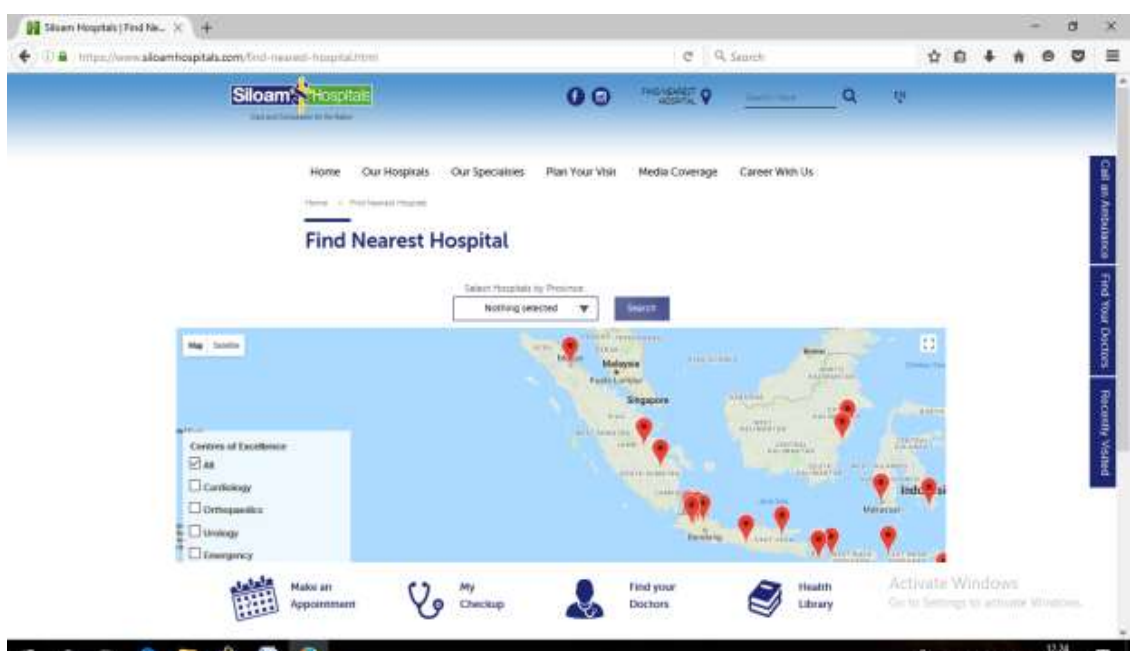

\# 8 a c a no

Gambar 6: Tampilan menu find nearest hospitals

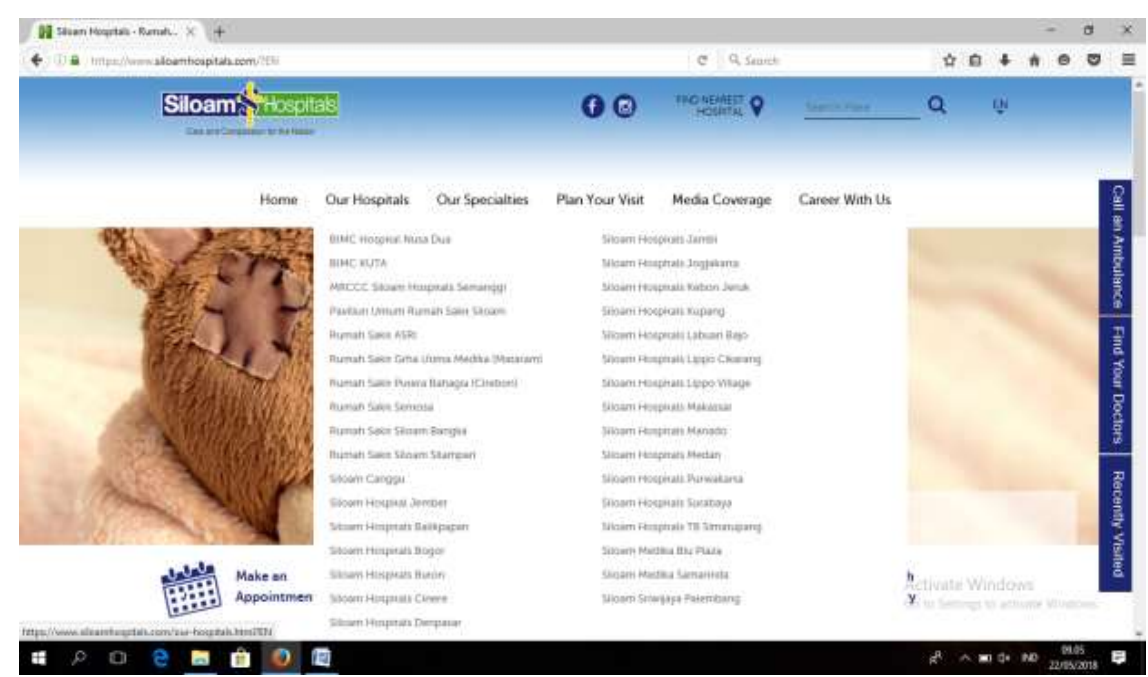

Gambar 7: Tampilan menu our hospital 


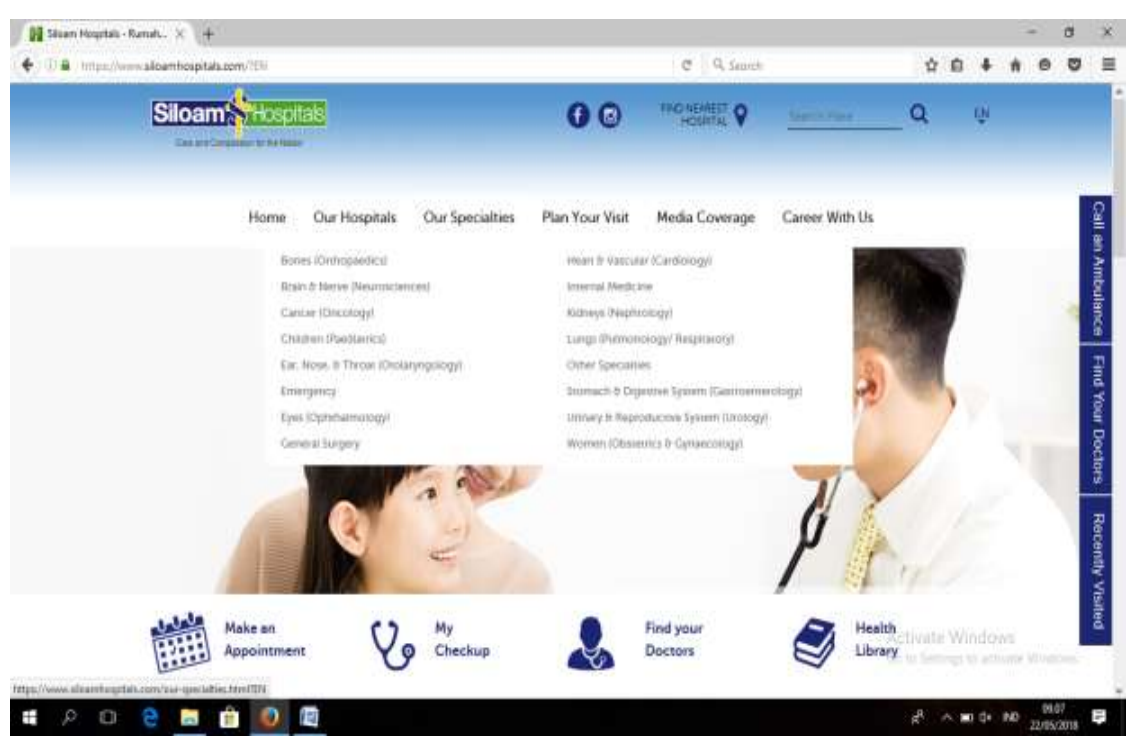

Gambar 8: Tampilan our specialities RS Siloam Palembang

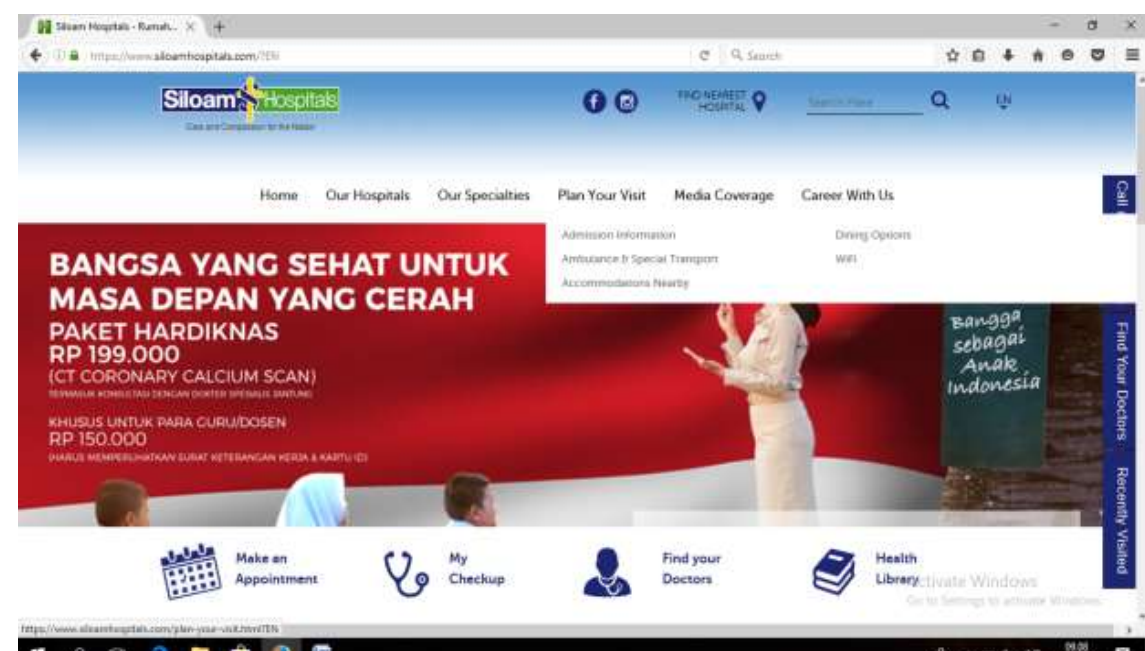

a 6 a

Gambar 9: Tampilan plan your visit.

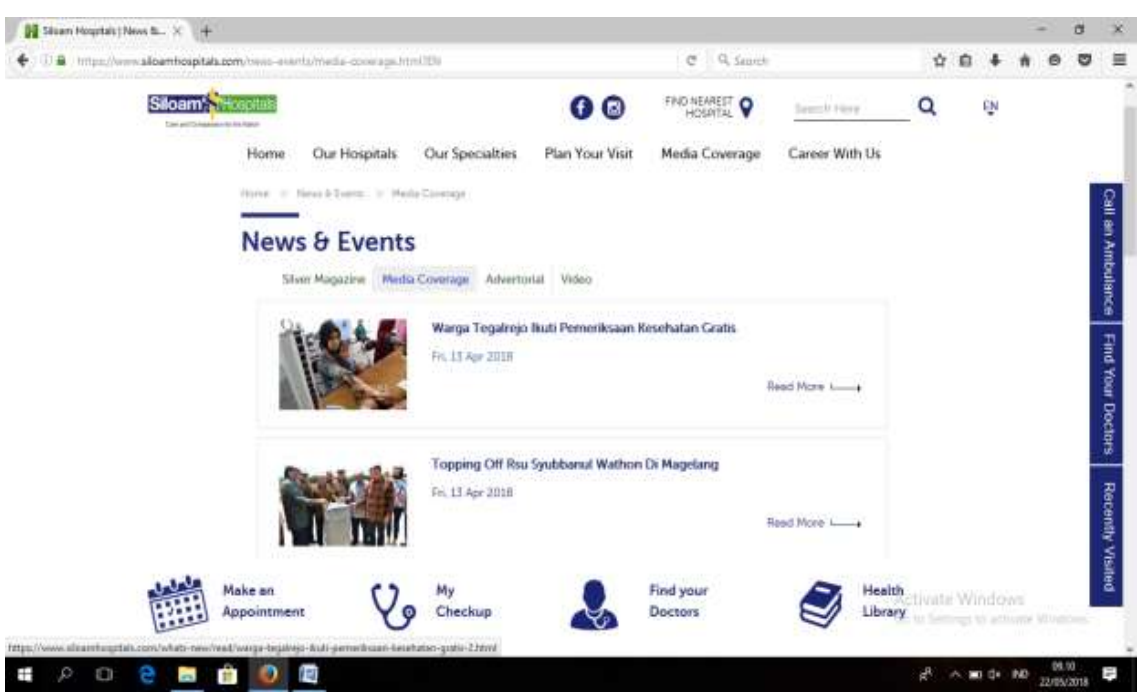

Gambar 10: Tampilan menu news event 


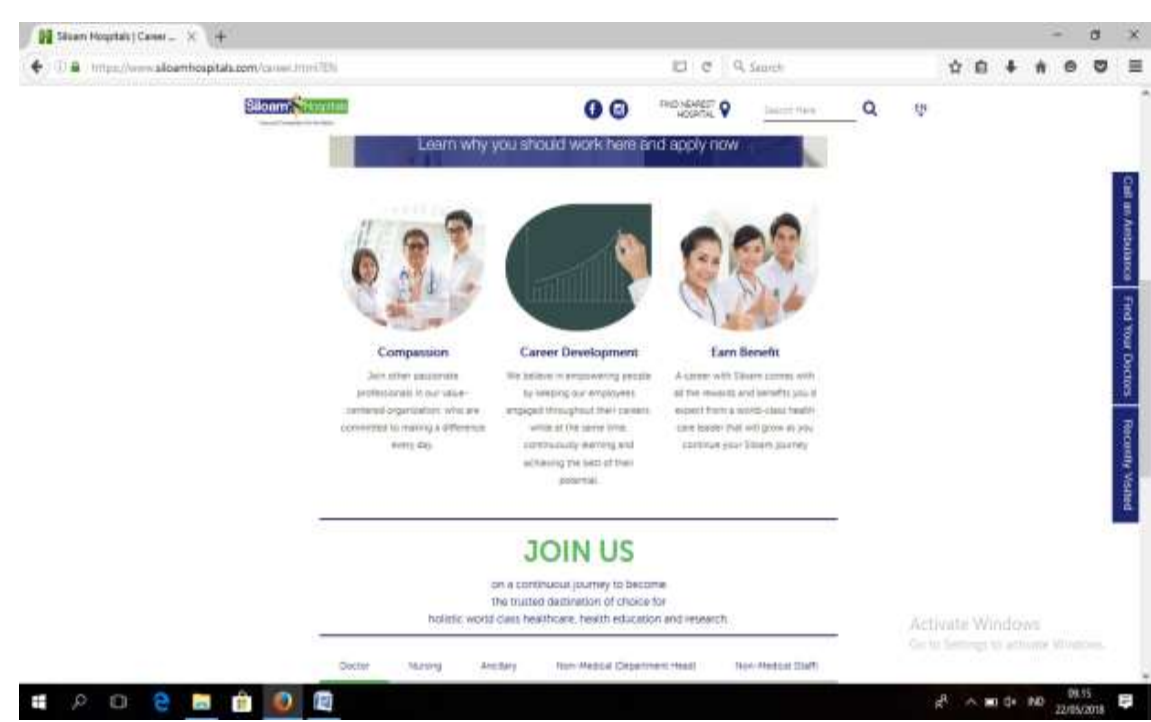

Gambar 11: Tampilan carrer with us.

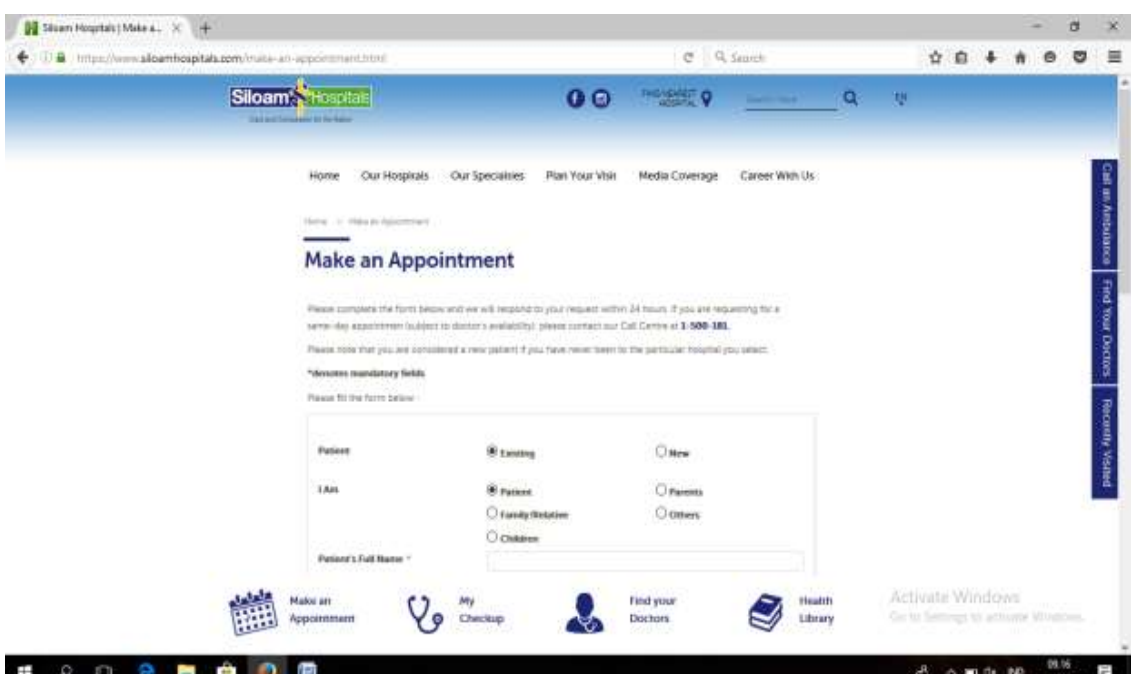

Gambar 12: Tampilan menu make an Appointment

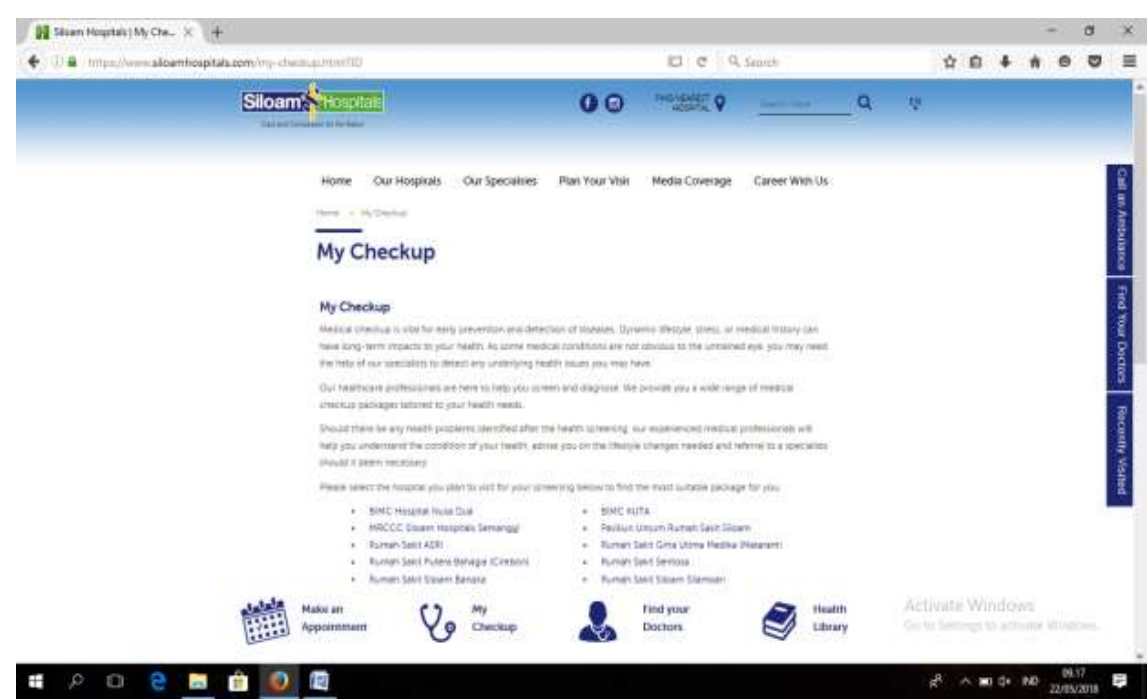

Gambar 13: Tampilan menu my checkup. 


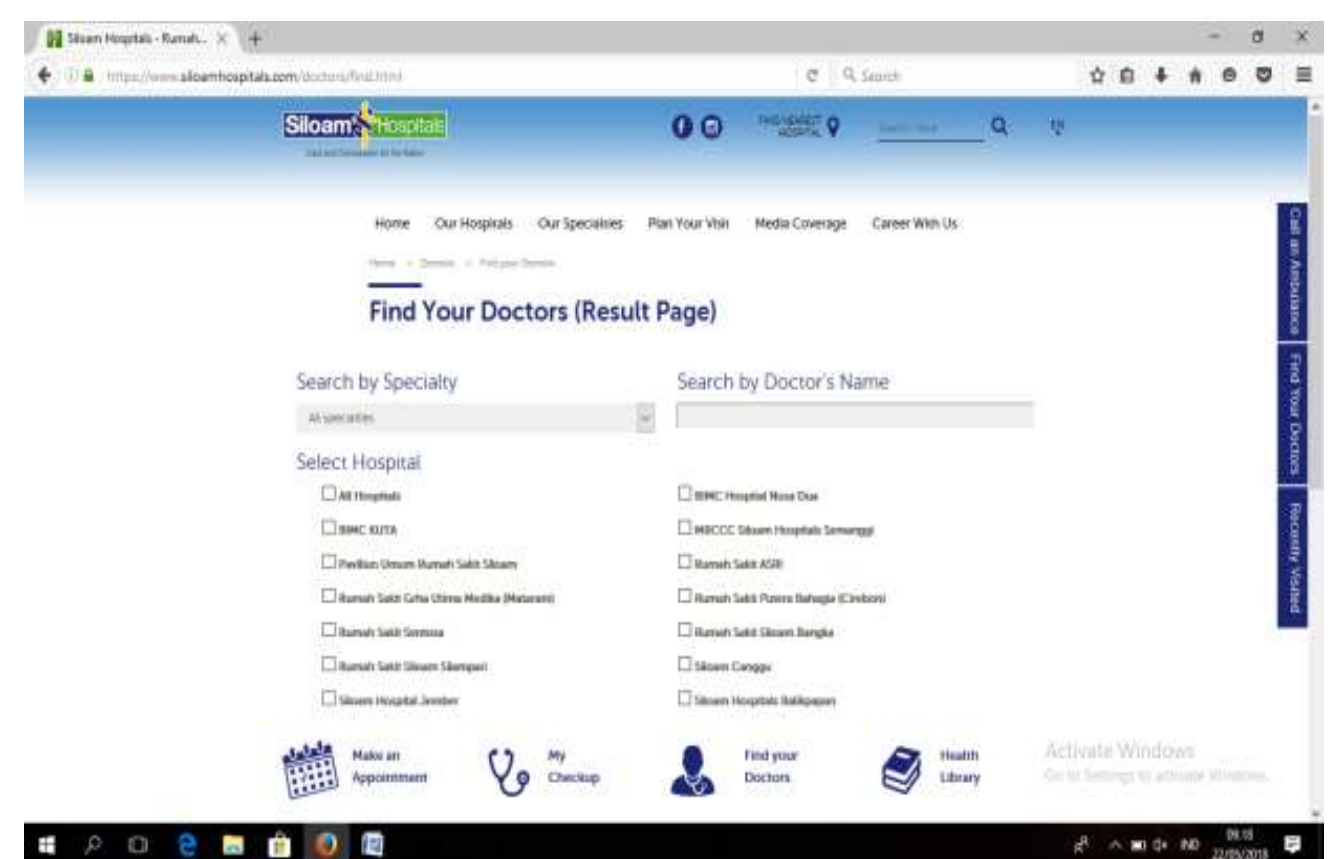

Gambar 14: Tampilan menu find your doctor.

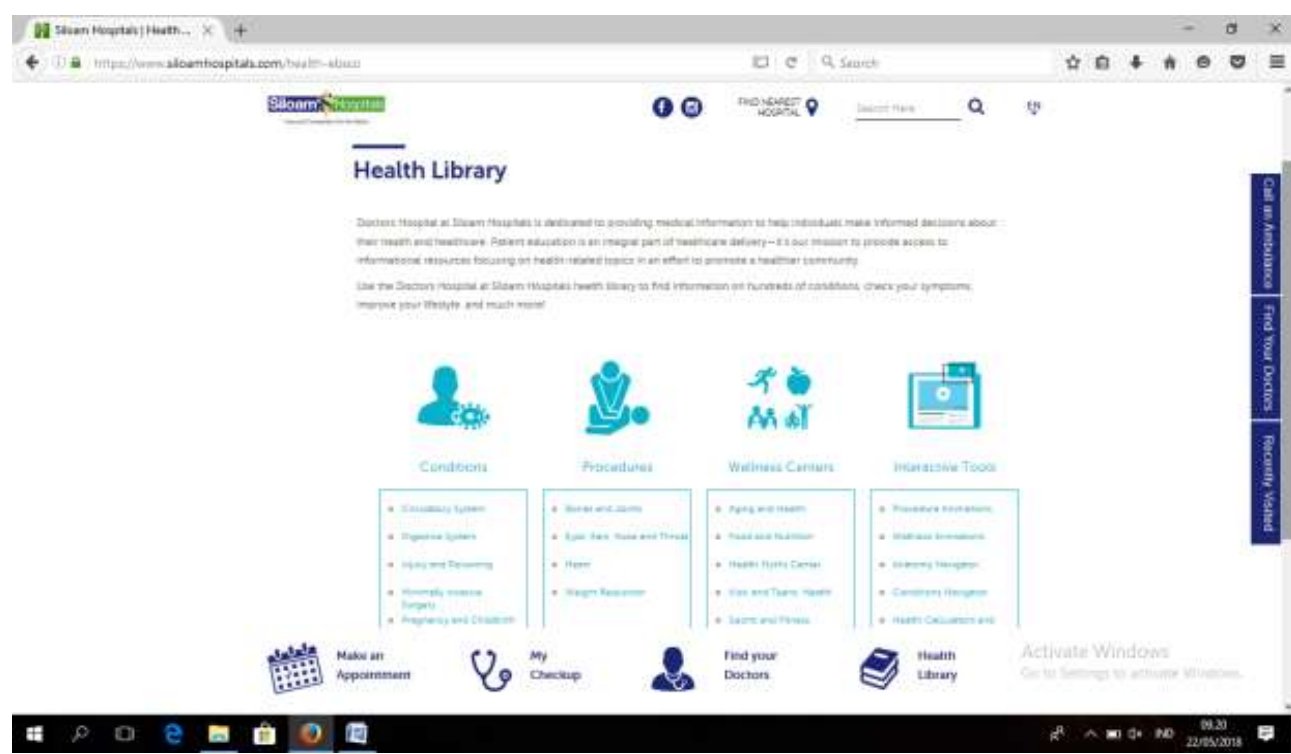

Gambar 15: Halaman menu healt library

Selanjutnya adalah menentukan nilai rata - rata dari penilaian responden. Dimana dari 10 responden didapat jumlah nilai sebesar 750 dan di bagi 10, maka nilai rata-rata yang didapat adalah 75, dimana dapat dilihat pada tabel 2 di bawah ini. Setelah mendapatkan hasil akhir selanjutnya adalah menentukan grade hasil penilaian. Untuk menentukan grade hasil penilaian ada 2 cara yang dapat digunakan.

Tabel 2: Hasil Penilaian Responden 


\begin{tabular}{ccc}
\hline Responden & Hasil & Skor \\
\hline 1 & $24 \times 2,5$ & 60 \\
2 & $28 \times 2,5$ & 70 \\
3 & $32 \times 2.5$ & 80 \\
4 & $28 \times 2.5$ & 70 \\
5 & $30 \times 2.5$ & 75 \\
6 & $28 \times 2.5$ & 70 \\
7 & $32 \times 2.5$ & 80 \\
8 & $36 \times 2.5$ & 90 \\
9 & $30 \times 2.5$ & 75 \\
10 & $32 \times 2.5$ & 80 \\
& Rata - rata & $750 / 10=75$ \\
\hline
\end{tabular}

Penentuan pertama dilihat dari sisi tingkat penerimaan pengguna, grade skala dan adjektif rating yang terdiri dari tingkat penerimaan. Penentuan yang kedua dilihat dari sisi percentile range (SUS skor) yang memiliki grade penilaian yang terdiri dari A, B, C, D dan F. Dari dua cara penentuan hasil penilaian tersebut maka dapat dilihat hasil penilaian sebagai berikut:

\section{Acceptability, Grade Scale, Adjective Rating}

Penentuan Acceptability, grade scale, adjective rating digunakan untuk melihat sejauh mana perspective pengguna terhadap website RS Siloam Palembang. Untuk menentukan Acceptability, grade scale, adjective rating maka dilakukan perbandingan hasil penilaian rata-rata responden sebesar 75 . Untuk itu dari hasil penilaian yang diberikan responden maka hasil penilaian terhadap website RS Siloam Palembang serta Tingkat penerimaan penggunaan masuk dalam kategori acceptable

a. Tingkat grade skala masuk dalam kategori $\mathrm{C}$

b. Adjektif ratting masuk dalam kategori good.

Sesuai dengan hasil penilaian tersebut maka website RS Siloam Palembang dapat digunakan dengan mudah oleh pengguna untuk mendapatkan layanan informasi serta penunjang kegiatan pengguna terdapat tiga kategori yaitu not acceptable, marginal dan acceptable. Sedangkan dari sisi tingkat grade skala terdapat enam skala yaitu A, B, C, D, E dan F.dan dari adjektif rating terdiri dari worst imaginable,poor, ok, good, excellent dan best imaginable. Penentuan hasil penilaian dapat dilihat pada gambar 16 di bawah ini: 


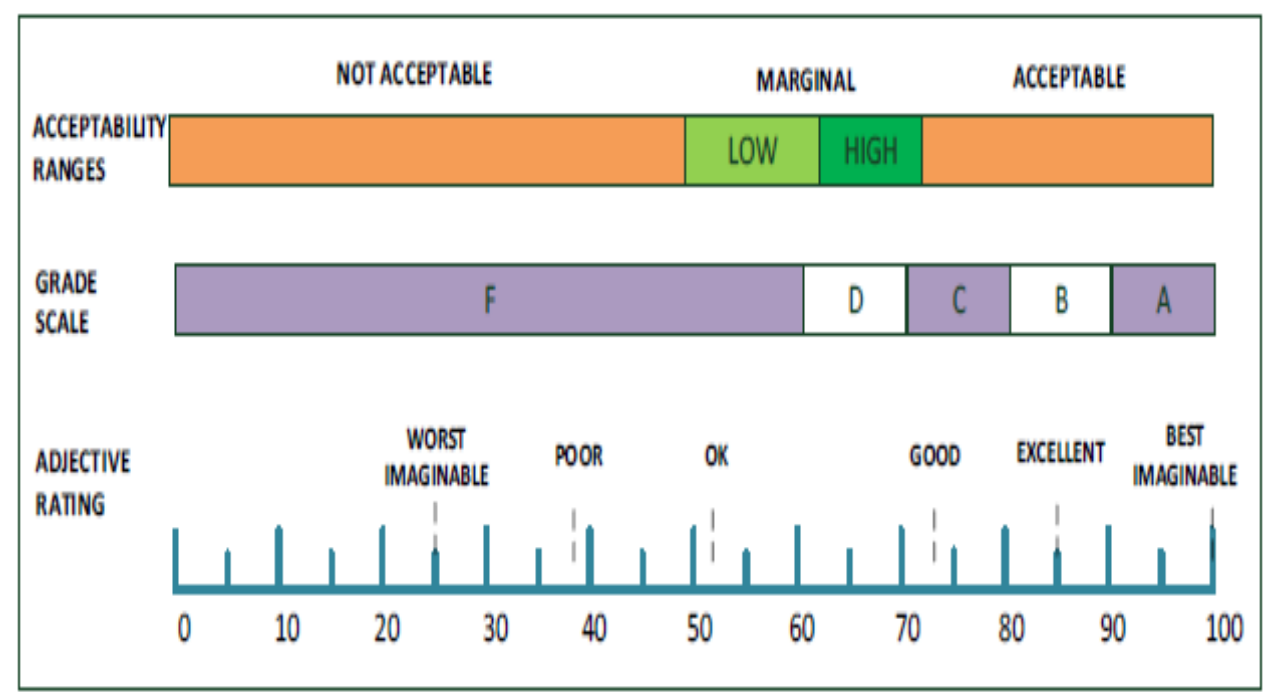

Gambar 16: Penentuan Hasil Penilaian (Bangor, Kortum \& Miller, 2009)

\section{SUS Skor percentile rank}

Penentuan hasil penilaian dengan cara SUS skor percentile rank memiliki perbedaan dengan cara penilaan Acceptability, grade scale, adjective ratting. Perbedaan yang terjadi pada kategori penilaian, pada SUS skor Acceptability, grade scale, adjective rating dibedakan kedalam tiga kategori. Untuk itu dalam menentukan SUS skor percentile rank seperti ketentuan sebagai berikut [8]:

a. Grade A: dengan skor lebih besar atau sama dengan 80,3

b. Grade B: dengan skor lebih besar sama dengan 74 dan lebih kecil 80,3

c. Grade C: dengan skor lebih bear 68 dan lebih kecil 74

d. Grade D: dengan skor lebih besar sama dengan 51 dan leih kecil 68

e. Grade F: dengan skor lebih kecil dari 51

Berdasarkan ketentuan penentuan hasil penilaian SUS skor maka hasil penilaian responden terhadap website Rumah sakit Siloam sebesar 75 berada, pada grade B. sehingga website Rumah Sakit Siloam dapat digunakan dengan mudah oleh pengguna untuk mendapatkan layanan informasi serta penunjang kegiatan perkuliahan.

Dari dua proses penetuan hasil penelitian yang telah dilakukan baik secara Acceptability, grade scale, adjective ratting maupun secara SUS skor percentile rank dapat dilihat perbedaan dari hasil akhir penilaian. Kondisi tersebut disebabkan adanya perbedaan sudut pandang dalam proses penentuan hasil penilaian. Penentuan pertama dilakukan berdasarkan Acceptability, grade scale, adjective ratting dimana satu sama lain berkaitan sedangkan SUS skor percentile rank hanya melihat dari sisi rank. Namun secara umum hasil penilaian reponden terhadap website RS Siloam Palembang dapat dikatakan baik atau dapat dimanfaatkan oleh pengguna akhir. 


\section{SIMPULAN}

Dari hasil penelitian dengan bantuan 10 orang perwakilan responden dengan hasil penilaian rata-rata responden adalah 75 dapat ditarik kesimpulan bahwa terdapat perbedaan hasil akhir antara analisa dengan Metode Usability Testing dengan System Usability Scale (SUS). Apabila menggunakan Metode Usability Testing, maka termasuk dalam skala grade C dengan kategori good. Sedangkan dengan menggunakan System Usability Scale (SUS), maka analisa akhir dari hasil penilaian responden adalah termasuk ke dalam grade B. Oleh karena itu, dapat diketahui bahwa terdapat perbedaan penentuan analisa hasil penilaian responden, jika Metode Usability Testing penentuannya berdasarkan Acceptability, Grade Scale, Adjective Rating sedangkan dengan Sistem Usability Scale (SUS) hanya ditentukan berdasarkan rank yang telah ada. Kesimpulan akhir dari kedua penentuan analisa penilaian responden ini bahwa website RS Siloam Palembang telah termasuk ke dalam penilaian baik dan dapat digunakan oleh seluruh pengguna.

\section{Referensi}

[1] M. Husin, "Evaluasi Penggunaan Website pada Rumah Sakit Muhammad Husein Palembang dengan menggunakan Metode Usability Testing," Skripsi Mhs. TI S1, 2013.

[2] D. R. Sari, "Evaluasi Penggunaan Sistem Informasi Akademik Universitas Bina Darma menggunakan Metode Usability Testing," Lap. Penelit., 2015.

[3] P. D. Sugiyono, Metode Penelitian dan Pengembangan. Research and Development / R \& D, 2015.

[4] M. Z. Yumarlin, "Evaluasi Penggunaan Website Universitas Janabadra dengan menggunakan Metode Usability Testing," Inf. Interaktif, vol. 1, no. 1, pp. 3443, 2016.

[5] I. W. Ardiyasa, "Pemanfaatan Raspberry PI dan Webcam Untuk Layanan Monitoring Ruangan Berbasis Web," in Proceedings Konferensi Nasional Sistem dan Informatika (KNS\&I), 2015.

[6] R. N. Dasmen, "Implementasi Raspberry Pi 3 sebagai Wireless Access Point pada STIPER Sriwigama Palembang," J. Inform. J. Pengemb. IT, vol. 3, no. 3, pp. 387-393, 2018.

[7] S. F. Aristo, "Pengaruh Produk, Harga dan Promosi terhadap Keputusan Pembelian Konsumen woles chips," PERFORMA, vol. 1, no. 4, pp. 441-447, 2016.

[8] A. Wijaya and Rasmila, "Evaluasi Quality of Service Jaringan Internet (Studi Kasus: RS Kusta Dr. Rivai Abdullah Palembang)," Sisfotek (Sistem Inf. dan Teknol., vol. 1, no. 1, pp. 186-192, 2017. 